\title{
A Practical-Theological Phenomenology of Joy: Learning from L'Arche
}

\section{Introduction}

When I arrived at Effatha House, one of the houses of L'Arche Kenya, I was excitedly greeted as Mtu wa furaha-Man of Joy. The warm welcome, the laughter and the apparent joy in Effatha House set the tone for my six-day stay in L'Arche Kenya, and for my research on joy in this community. I wanted to find out what joy looks like in the L'Arche communities, where people with and without learning disabilities live and share their lives together. Apart from L'Arche in Kenya, I visited the communities in Inverness, Manchester and Trosly. This article presents a phenomenological description of what joy looks like in the context of these communities. Working within a practicaltheological framework, the description of joy draws extensively on participant observation and interviews in the just-mentioned communities. Furthermore, this article will offer a theological reflection of joy in L'Arche, primarily based on the writings of Jean Vanier and Henri Nouwen.

Why study joy, and why in the context of L'Arche? The topic of joy is of central importance to the Judeo-Christian tradition. The Scriptures are full of stories of celebration, songs of praise, and prophesies of flourishing. Jesus said he came to bring fullness of life (Jn 10:10), and indeed, joy is one of the fruits of living by the Spirit (Gal. 5:22-25). The eschatological future is one where God "will wipe every tear from their eyes"; where "there will be no more death or mourning or crying or pain" (Rev. 21:4, NIV). All of these instances might be seen as expressions of joy, even though joy is a more complex phenomenon than only an exuberant positive emotion - the connection with woundedness in particular will become clear in this article.

The centrality of joy in Scripture notwithstanding, various theologians have recently claimed that the topic has not received as much attention as its dominance in Scripture would suggest. The more well-known and sustained reflections on a theology of joy come from Jürgen Moltmann (1973) and Karl Barth (1956, esp. p. 374-385). The recent volume Joy and Human Flourishing, edited by 
Miroslav Volf and Justin Crisp (2015), tries to fill the gap in theological reflection on joy. Their volume includes not only systematic theological perspectives, but also biblical studies, spirituality and pastoral care. In the field of practical theology, sustained reflection on joy is largely absent, with the notable exception of Mary Clark Moschella's Caring for Joy: Narrative, Theology, and Practice (2016). She grounds her reflections on joy in particular people and groups, one of them Henri Nouwen and the L'Arche communities. Finally, the initiative of the 'Theology of Joy and the Good Life' project is noteworthy. This project, directed by Miroslav Volf at the Yale Centre for Faith and Culture, has sought to put joy as a central theological category back on the academic agenda. The research on which the present article is based, was supported by a grant from this project. The present article, therefore, aims to contribute to the recently reinvigorated discussion on theologies of joy, by looking at a particular exemplar of joy, i.e. L'Arche.

Why L'Arche? First, a striking feature of the L'Arche communities, as can be seen from various films, documentaries, and writings, is the presence of joy. L'Arche communities are communities where people with learning disabilities (so-called core members) and without (socalled assistants) share their lives together. ${ }^{1}$ Both core members and assistants testify that L'Arche is a joyful place, and that joy is of great importance to them. Joy is indeed "very important" in the words of Joshua, core member in Kenya. Peter, assistant in the same place, says: "I don't know what life would be if it wasn't joy." L'Arche communities may be seen as exemplars of joy, and therefore may enrich a theology of joy. Of course, this invites the question what joy is, which is a question that this article seeks to answer, in the context of L'Arche.

Second, one of the paradoxes of L'Arche is the reversal of prescribed roles. The emphasis in L'Arche is on building friendships and sharing in each other's lives, contrary to some (if not many or most) other care institutions. One might assume that the assistants support and care for the core members, which indeed they do. However, many of the assistants say that they often feel supported and cared for by the core members. In the words of James, an assistant in Inverness, L'Arche is a place of "mutuality." Accordingly, core members become the teachers of the assistants. ${ }^{2}$ L'Arche 
embodies one of the paradoxes of the Christian faith which St. Paul points to, namely that God uses the weak to confound the strong, and the foolish things of the world to confound the wise.

Therefore, the lived reality of joy in L'Arche is a good place from which to theologise about joy. The premise is that L'Arche communities have a lot to teach about a theology of joy. This article includes voices of both core and staff members.

Here we should state one important disclaimer. This article focuses on joy. The impression may be given that L'Arche is only a place of joy, friendship and belonging. However, living in any community should not be romanticised. There is also a lot of struggling, pain, misunderstanding, and not everyone will find the joy and satisfaction of living in L'Arche as others do. Vanier is the first to admit this (see in particular Vanier, 2007). In the words of Morag, an assistant in Manchester, "there's a lot of sorries and a lot of thank you's." In the section on joy according to the assistants, we will return to this.

The first part of this article outlines the methodology of the research. The second and third part describe joy in the context of L'Arche, based primarily on participant observation and interviews in the four communities. The fourth section gives a theological reflection on joy in L'Arche. In this way the article arrives at a practical-theological phenomenological description of joy.

\section{Methodology}

This article is based on a practical theological, qualitative research project, conducted in the summer of 2018. The participant observation and interviews were carried out by Léon van Ommen.

Throughout this article, reflections on these observations and interviews are at times written in the first person singular, and in those instances refer to Léon. All data was analysed and theologically reflected on by both Julie Land and Léon van Ommen. Four L'Arche communities were visited during April, May and June. Due to the limited duration of the project and for practical reasons it was only possible to spend a short time in each community: four days in Inverness, seven in Manchester, and seven in Kenya. The founding place of L'Arche, Trosly, was also visited for two days, where Jean Vanier, the founder of L'Arche, was interviewed. When we speak about L'Arche in this article, we 
refer to these four communities. Apart from participant observation - with an emphasis on participation -just over thirty semi-structured interviews with both core members and assistants were conducted. All interviews took place during these visits with the communities, except for the interview with Phoebe, which took place by Skype, a week after returning from Inverness. Core members were supported in the interview by an assistant, and in Kenya this assistant translated from Kikuyu or Swahili to English. The amount of time participants had been involved with L'Arche varied. Other than one assistant, who had been with L'Arche only seven weeks, the involvement of all others ranged from six months to over thirty years. The following table shows the number of formal interviews in each community.

\section{INSERT TABLE HERE}

All core members were able to give their informed consent. For two core members in Inverness and one in Manchester verbal and/or written consent was also obtained from one of their parents. The core members agreed to the interview beforehand, thereby giving their verbal consent, and at the beginning of each interview the consent form was read with them by an assistant, who further explained what they were consenting to (cf. Nind 2008, pp. 6-8). The participant's identity was anonymised in the transcription of the interviews and in the analysis. All names of participants in this article are fictitious, except for the community leaders and Jean Vanier because of their distinct roles, and one assistant in Kenya (Peter) who preferred to be mentioned by his real name. Those mentioned by their real name all gave explicit consent to do so.

The interviews were transcribed by an external transcriber and at some minor points corrected by Léon (for example in the case of particular names of places that the transcriber would not have known). A phenomenological attitude was applied, following this method as outlined by Linda Finlay (2008). The reason to adopt a phenomenological attitude to the project was because of the core questions it asks, which are phenomenological questions and try to arrive at the essence of the phenomenon: What is joy (in the context of L'Arche) and what does it look like? 
In the interview with Jean Vanier, he said that joy is one of those things that is hard to define, "but you can see signs of it." There is something about joy that eludes textbook definitions. I asked all my interviewees, if I was to teach a lecture on joy, back at the university, what should I tell my students, or what would they tell them. Very often the response was - from both core members and assistants - "Come and see." That is what we did in this project, and in the following pages we invite the reader to look with us at what we saw.

\section{What does joy look like according to core members?}

I walked up the beautiful driveway to the stately house that is Braerannoch, the first and biggest house of L'Arche Inverness, on which premises the workshops are also located. This was my first time to a L'Arche community, and my first time that I would spend considerable time with people with learning disabilities. With a mixture of anxiety and expectation I rang the doorbell. The door was opened by Joan, a core member of the community. Joan let me in but did not say much to me. Immediately an assistant came as well. Joan told the assistant that she had opened the door, and I sensed she said it with some pride. The assistant praised her for opening the door.

This anecdote may seem unimportant, but as a matter of fact it is illustrative of one of the essences of joy in L'Arche, as we were to learn later through observation and interviews with core members. One theme that stands out in the interviews with core members is that they appreciate that they are given opportunities (the other themes, which we will discuss here, are relationships, happiness, and welcome). This includes the opportunity to learn and to work, to be involved in welcoming guests, to talk with people or give a speech at the funeral of a fellow core member, to be independent. Independent here does not mean individualism, apart from community. It means that core members are encouraged to do things themselves if they can, and explore what they can do themselves, rather than the assistants in some paternalizing way doing things for them. For Joan this meant opening the door, and she was duly praised for it.

Opportunities to learn are often present in the workshops. Many L'Arche communities have workshops, where L'Arche members spend time together, meanwhile making candles, doing 
woodwork, making bread or baking, cooking, gardening, or other activities. When asked what they enjoy about L'Arche, a good number of core members emphasised this opportunity to learn and to work. These opportunities to learn and work take place in community with one another, the emphasis in these workshops is not productivity and efficiency, but on being together and valuing one another in these spaces.

The theme of opportunities might be interpreted against the background of societies that often deny people with learning disabilities space to develop their skills and talents. When L'Arche gives opportunities this is not with the purpose of being valued for one's achievement, but with the purpose of empowering and enabling and ultimately human flourishing. A sense of purpose and pride was almost tangible in the Kenya community, as well as in others. For example, Oboke from Kenya recalls that he was given the opportunity to try different workshops and learned a lot.

I have learned to cook here. (Eggs, that is what he said [translator's note]). Rice. I didn't know anything to do with the phones, now I know how to use a phone. And I want to buy a phone of my own. Nokia touch, a smartphone. So I work very hard here, getting that. Sometimes I have a dream that one day I will work here in town, too. I'm very grateful that I have learned how to work, and I'm sure I can work in town.

Not all core members have similar dreams to Oboke, but his gratefulness and joy of being given the opportunity to work and learn is shared by all. Mary responds to the question what makes her feel happy as follows, talking about her involvement in the candle making workshop:

When I doing concentrate on this, looking at, polishing and pouring the wax into a sifting glass. We all take turns to: well Maihra is always doing everything, and then polishing is really good. Don't get to sell the candles and...I remember Lena - write the labels, got to be very careful as well, yes. 
The last sentence in the quote expresses something of the pride that many core members have in working in the workshops. Through working in the workshops and the positive environment of the community, both in and outside of the workshops, the core members grow in confidence. And so, in a spirit of mutuality, Mary taught me how to make a trellis out of willow branches for the peas to grow against in the garden. We enjoyed working together and Mary enjoyed teaching me how to do it. In the interview I asked her about it, and she confirmed, laughing, that it had made her happy.

The joy of working together leads to the next observation and 'essence of joy,' which is relationships. The workshops do not only give an opportunity to work and learn but they provide a context in which people develop relationships. Through the stories of the core members it becomes clear that relationships are as important as the opportunity to learn, if not more. In their stories, what they say about the workshops is often simultaneously a commentary on the relationships in L'Arche. Mary recalls what she had learned in the garden workshop and concludes: "I think it's really good to learn new things, and get along with people. It's fantastic. People can talk to us quite nice, it just make me relax." Similarly, when Oboke talks about the workshops, he talks at the same time about the people working there. Also for Jennifer working in the kitchen (one of the workshops in L'Arche Kenya) is intertwined with enjoying the relationships with other core members and with the 'mom' leading the kitchen workshop. We hear about her happiness through the words of the translator, when she tells about how they play with 'mom,' and the fun that they have with her in the kitchen, like tickling her. The workshops give the core members an opportunity to learn and work, to feel valued for their gifts and talents, for their contribution. To reiterate, this is not to communicate a placing of gifts, talents, contribution, or a person's value into some achievement shaped box. The workshops create a context in which an atmosphere of mutual appreciation can be developed and in which relationships are shaped and deepened.

Relationships are built through sharing life together. Nora, a core member in Manchester, is very active. She likes the chance L'Arche gives her to be independent, but she also likes to do 
activities together with others, for example swimming together with one assistant. Jane, another core member in Manchester, likes to do the 5k Park Run with Kevin, the community leader, every Saturday morning. For Mary, joy is friendship, talking to her friends, and the nice staff. Similarly, Patty, also a core member in Inverness, talks with great affection about the staff members. In all interviews with core members, and from my observations, it is clear that for the core members joy cannot be seen apart from relationships of the kind that L'Arche fosters. Those relationships - both with core members and assistants - are marked by friendship, sharing, caring, and being given opportunities.

A third hallmark of joy in L'Arche, and in particular with core members, is difficult to capture in one word. It has to do with feeling happy, laughing, dancing, having fun, throwing parties, organising celebrations, teasing and joking, and being silly. That does not mean that joy is always exuberant, but it would be hard to speak about joy without these things. Joy does look like the joyful dancing together of Ciaran and Koro, teasing 'mom' in the kitchen (Jennifer), and the endless singing of Jane. Joy does look like celebrating every new visitor in L'Arche Kenya with humorous speeches, music and dancing, as I experienced myself; or welcoming back the community leader after he had been away for two weeks, with a special decorated cake, and again dance, music, food, and above all, being together and celebrating the fact of being together. All these expressions of joy cannot be seen apart from relationships, an essence of joy mentioned above.

Finally, and perhaps a bit more subtly, welcome seems to belong to the essences of joy for the core members. With one core member, Joshua from Kenya, welcome and joy go together. At the end of our interview I asked him whether there was anything else he wanted to say about joy. His answer was: "I'm very happy when guests come or visit us and they involve me in what they do. And they give me a chance to give them a welcome. More specifically, I like to take people to Thomson Falls." Also Gordon, a core member in Inverness, emphasises welcome when he interrupts a conversation I had with his assistant, saying "They are always welcome!" (meaning my students). Oboke kindly asks whether I have a family and invites us all to come to L'Arche Kenya. The welcome I 
received in Kenya as Mtu wa furaha, and also in Inverness, Manchester and Trosly, was overwhelming. Not all core members would emphasise this in their interviews, but from the participant observation it was clear that L'Arche is a very welcoming place.

Does welcome belong to the essence of joy? For some core members it clearly does, for others it appears less evident. Nevertheless, L'Arche is a joyful place in many ways (even if it is also a place where there is pain and woundedness - we will return to that later), and it is a place of welcome. The overwhelming welcome says something about the communities. The response "Come and see" to my question, what should I tell my students about joy in L'Arche, is a response that expresses the welcoming atmosphere of L'Arche. Everyone is welcome to come and experience the joy in L'Arche. Welcome is strongly related to relationships as an essence of joy. In relationships that are marked by friendship and care, as discussed above, a warm welcome is extended towards each other. For many core members there is joy in welcoming visitors. It would be hard to see joy in L'Arche apart from the welcome the members themselves receive and that they extend to visitors. Therefore, welcome is arguably another essence of joy.

In sum, when listening to core members and joining them in their communities, four themes appear constitutive of joy for them: being given opportunities, relationships, happiness, and welcome. This is what joy looks like and its' essence for the core members in our sample. We will now turn to the question what joy looks like for the assistants.

\section{What does joy look like according to assistants and staff members?}

Joy has an infinite number of faces. Joy is watching that same awful comedy for the thirteenth time with the core member, who plays back that one scene all the time, and being caught up in the tears of laughter streaming down her face. Joy is going out with the minivan to the cinema, or the park to eat an ice-cream. Joy is making bread together. Joy is the core member spontaneously giving you a hug or a kiss. Joy is a core member tapping his seat, making clear he wants you to sit next to him. Joy is expectancy and welcome: please come and visit my house. Joy is also seeing growth in each other, core members and assistants alike, and the deepening of relationship. Joy is in the core member's 
remarkable sense of knowing you are not well, and eager to comfort you. Joy is in the many parties and celebrations, fun and laughter and jokes, but joy can also even be in the difficult times. Joy can be "holding somebody's hand at the bottom of a big hole" (Kevin, L'Arche Manchester). Joy is in going through a tough time and discovering that it did not kill the relationship. Many more examples of what joy looks like can be given. What is it in all these stories that were gifted to us by the communities that belong to the essence of joy? In our interpretation, for the assistants the answer is: relationships and being oneself. These two themes might be thought of as prisms through which the light (or joy) breaks into all these different faces of joy. A third needs to be added though, and that is the curious observation of many assistants that joy and woundedness go hand in hand.

First relationships. For all assistants joy was connected to relationships. While relationships and joy leaped off the pages of every interview, it is not easy to describe. As Penelope put it simply but profoundly: "Of course there is a joy when you know each other. I don't know how to explain that..." There is joy in knowing another and being known. In response to the question what makes L'Arche a joyful place, she responded by emphasising unity and coming together. Like several other assistants Penelope describes the relationships in L'Arche as family-like. Other assistants describe the relationships in L'Arche as friendship. Rhona, for example, likes L'Arche because of the friendships with core members and assistants. The same is true for Maurice, community leader of L'Arche Kenya. "So relationship I think is key, okay? Not just doing things for, but the relationship is key. And the relationship of mutuality, the relationship of giving and receiving, the relationship of reciprocity, that makes L'Arche a place of joy." In both images of family and friendship, mutuality is at the heart of the relationships. Joy is in being together, sharing life together, and getting to know each other.

Often these family-like relationships or friendships take the form of just spending time together. Rhona enjoys the little things, like "sitting in the garden, having a cup of tea for breakfast, that's, you know, I like that sort of spending time with people." Or, in Morag's words: "Yeah, I think L'Arche is a place of dance parties and whipping each other with tea towels, and cups of tea and 
watching ridiculous films again and again and again. And excitement about sun cream." The little things are closely related to the idea that joy is in the present moment, as expressed by various assistants. For Keira, joy is "something where I am living in a moment, really presently, and feeling everything that comes from whatever it is that I'm being given, or I'm experiencing ... and often are really small things." Joy in the little things and present moment is not fleeting or superficial. Keira speaks of "bone-deep joy." For her joy in L'Arche is tied to being with others in relationship, in particular with core members. Joy is often expressed through laughter, an impromptu comment, and all those little things, yet it is "coming from a deep place."

For Phoebe, assistant in Inverness, the source of joy is sharing oneself, opening up, and therefore inherently with relationships. Sharing means "to not just share, you know, your hands, your help, but actually yourself as well. I think that is for me, actually that is the source of joy." Phoebe theorises that when people cannot open up themselves to another, they may feel lonely. Peter would probably agree with Phoebe. For him true joy "is found in oneself but also in giving a chance to others. Joy can never be complete if I'm alone." For Keira joy is also tied to relationships and sharing joy in that relationship. When one feels free to share oneself, it brings joy. It follows, interestingly, that according to Phoebe loneliness is the opposite of joy. Kimutai speaks also about sharing joy in relationship, which relates even to his definition of joy: "Joy to me is - when I find something that gives me happiness, internal happiness, and then I bring it out through a smile, that would be my definition of joy." While sharing is not mentioned explicitly by all assistants in our sample, most of them would probably agree that this is part of being in relationship, which in turn is for all of them a key to joy.

The second key theme regarding joy in the stories of the assistants concerns the ability to be oneself, and is again dominant in these stories. This theme is closely related to the theme of relationships. The relationships that the assistants (and core members) talk about are characterised by acceptance of each and every person, and therefore making space to be oneself. When people 
are accepted as they are, they can be themselves. This is powerfully illustrated by the story of Jordan and by a fragment from the interview with Keira.

The story of Jordan is one of many similar stories that were told by members of L'Arche Kenya. These are stories about the exclusion of people with learning disabilities. Often people with learning disabilities are locked away in their homes because their parents are ashamed of them. Parents do not take their disabled children into public spaces, whether it is the market place or the church. I met this young man, Jordan, and I was told his story. When he still lived at home, Jordan was made to sit outside the house with a rope around his ankle, and at the other side of the rope was tied a goat. He was perceived as good for nothing else than goat-sitting. When he came to L'Arche, he did not speak, he was withdrawn, and he did not take part in activities. He has been living in L'Arche for several years now, and he has changed significantly. He speaks, he joins in, he makes a lot of jokes and has fun with his friends. Whenever the music is turned on, he starts dancing. I remember one night in the community when I sat with Peter at the table, after dinner. Peter and I were drumming with two plastic cups on the wooden table. (It was one of those very loud moments in Effatha house!) Jordan and his best friend started dancing and having a lot of fun by dancing quite silly. The Jordan in this dance can be himself. He has found friendship and the freedom to be silly, to dance, to enjoy. Jordan has discovered a community that accepts instead of rejects him; instead of being neglected he is now met with loving care; instead of being told he is worthless, the community lets him know that he is precious.

Keira comments on how acceptance does often come from the core members in the first place. It is worth quoting her at length, because she expresses what many assistants said in one way or another:

I feel like there are ways in which our society just is making people feel sadder, and lonelier, and inadequate, and kind of disconnected in a meaningful kind of, you know in any kind of, or not connected in a meaningful kind of way. But actually I think, I feel like L'Arche is just such an antidote to that, because it's just, it's so irrelevant 
what you are, where you went to university, you know, whether you own a home, all of those things that we get swept up in worrying about, it's just not important to people in L'Arche. You know, to core members it's like who are you? Like, can you sit and watch this awful comedy with me? Like, can you just be yourself with me, like can you share a bit of yourself with me? That's what I feel like the invitation from Shana [a core member] often is, is can you just be yourself? Can you let yourself be? Like, loved and joyful, like, it's almost like that's what I want and need, like, not all the other stuff that one or I can get preoccupied with. I think it is, yeah, I feel like it really offers something quite profound that I feel like is perhaps missing from what we are taught to aspire to.

The question of the core members, expressed by Keira's words, 'Can you just be yourself? Can you let yourself be?' is deceptively simple. The question might sound simple, but Keira's contrasting the question with society's norms shows how profound it is. The answer given by many assistants is that L'Arche is the place where they learn to be themselves. The answer to the question for many is 'Yes, I can be myself,' while at the same time recognising that this is a process.

Jordan and Keira show that being accepted and appreciated as you are brings deep joy. When people are accepted as they are, space opens up to be free and be oneself. That freedom is the opposite of the often-felt need to be successful and to keep up appearances, as Keira and others say. Peter's definition of joy is "being yourself" and that, when you are yourself, "people still appreciate you for who you are." However, Rhona makes it also clear that L'Arche is not necessarily about joy: "I think it's just about being real, being your real self and bringing your real self to other people and accepting their real self. And that can be joyful sometimes, and sometimes not." With that statement we come to the third theme that emerged from the interviews with assistants: joy and the difficult moments of life.

Third, joy when things get tough. In our interview Vanier stated that woundedness turns into joy when people "discover that they are loved, just as they are. So everything then is changed." In 
order to understand this profound statement, which Vanier bases on having lived in L'Arche for more than fifty years, we need to look at what he and others mean by woundedness or other expressions of the difficult moments in life. Vanier talks in this interview, and in many of his books, about the pain many core members feel or felt because of being rejected by society, and sometimes by their own family and parents. The story of Jordan (above) is a painful illustration of such rejection. Such rejection may lead to putting up defence mechanisms, according to Vanier, and this contrasts with joy. Vanier: "And I think that, as I say, the opposite [of joy] is our defence mechanisms: protection, defence, fear, need for security." We can add here Phoebe's suggestion that the opposite of joy is loneliness. The way Vanier talks about defence mechanisms makes clear that they indeed lead to loneliness. Vanier claims that everyone has constructed defence mechanisms.

L'Arche is a place where people learn gradually to drop those mechanisms. The teachers of this process are often the core members. Vanier (1992, pp.18-19) writes:

\footnotetext{
"They have been teaching and healing me. They have been teaching me that behind the need for me to win, there are my own fears and anguish, the fear of being devalued or pushed aside, the fear of opening up my heart and of being vulnerable or of feeling helpless in front of others in pain; there is pain and brokenness in my own heart."
}

This appears reminiscent of Keira's quote above in which she talks about L'Arche as an 'antidote' to the way society tends to make people feel sadder, and who agrees with Vanier that this is expressed in the importance many people attach to "where you went to university, whether you own a home, all those things that we get swept up in worrying about." So the woundedness that Vanier and others talk about is first of all the felt need to protect oneself from hurt, by putting up defence mechanisms that might look like anger, aggression, withdrawal, or the need to win or be successful according to society's values. These mechanisms stand in the way of joy. It is in being oneself, and knowing that one is precious (a theme we will return to later) that true joy emerges. 
The second way tough times are spoken about in the interviews, is in relation to community life. Living together in community is not easy. Community is a place where it is hard to hide, as various assistants said. Moreover, Calkina asserts that in order to have joy "you have to be genuine, with yourself and others around you. For you to have joy, you have to be open to criticism, open to change." Similarly, Phoebe, who emphasises that joy is in relationships, states that when "relationships involve differences, they become a place of challenge and change." We can almost hear Rhona's comment above in the background: "And that can be joyful sometimes, and sometimes not." But even if those difficult times are not joyful at the surface, Morag and Kevin both show how they find joy even in really tough times. Morag says:

I feel a real privilege that I get to share in people's lives. And, and in some really hard, hard times in people's lives. And people have, yeah, been there through my really hard times. And yeah, there's so much joy then in the experience of still being alive together almost.

Joy is in being alive together after going through hard times, Morag says. She grounds this in the privilege of sharing in people's lives, a theme we saw already. Sharing in someone's life in the way Morag talks about it, is related to friendship, to the idea of needing and being needed.

Kevin, the community leader in Manchester, reflects on this as well. It's worth quoting him at length, because he expresses in his own words how needing and being needed holds people together and brings joy, even in difficult times.

So the hard times in community: we have lived some really quite cripplingly hard things, things that could destroy community. Deaths, separation...in those moments of pain, conflict, disagreement, destruction, to still have that same sense of belonging, still have that same sense of I am needed, and I need you. You might be the person in great pain, even if you might be the person causing great pain, the sense that I am needed and need you is for me a source of great joy. Might not be 
fun, it ain't fun-but a sense of joyful rightness, a sense of joyful belonging ... And so those times of vulnerability and fragility are bizarrely still joyful because of a sense of belonging. Because of a sense of rightness. Because of a sense of being needed. And needing in exactly the same way as the times that are a laugh down the disco and down the red line. (thinking) Yes. Those things are the same even in painful and in happy times. Joy can still be the same.

This quote shows that joy can be found in tough times, and how it can go together with vulnerability and even suffering and woundedness. Acceptance, belonging and being needed are the point of convergence. Kevin and Morag show that joy and woundedness meet each other where people are accepted as they are, where each person is needed and belongs, no matter what. The joy is not in the woundedness itself - "it ain't fun" as Kevin said - but in the sense of belonging and being there with and for each other. For Kevin and others, it is difficult to speak about joy without speaking about the tough times as well. Strangely enough, in Kevin's words, "joy can still be the same."

The assistants told many stories of what joy looks like in their communities. My time spent in the four communities added many more stories. It is hard to do justice to all these stories and observations, all those joyful moments. Nevertheless, the themes of relationships and being oneself belong to the essence of joy in L'Arche, together with the observation that joy can be found even in tough times. The next question is how these themes are connected to the themes we identified with the core members, and how all of this might be interpreted theologically.

\section{Theological reflection}

We identified four themes as the essences of joy for the core members: being given opportunities, relationships, happiness, and welcome. How might they be related to the essences of joy as observed from the assistants, namely: relationships, being oneself, and the observation that joy can be found in tough times? The answer to this question also provides an answer to the potential critique on distinguishing so sharply between core members and assistants or staff members. Such a 
critique is justified, for L'Arche aims to overcome the distinction between carer and cared-for, and instead to live together as friends. Indeed, as many interviewees said, the relationships between core members and assistants are marked by mutuality. Core members are grateful for the opportunities and friendship being offered by assistants and fellow core members. Assistants testify to the profound lessons they learned from the core members. The distinction is overcome at the level of valuing each other in their common humanity. The distinction does remain in L'Arche, however, if only by simply the terminology used: core members and assistants. The distinction is valuable insofar the term 'core member' expresses the core of L'Arche: it is about creating an environment in which the gifts of people with learning disabilities are made known (cf. the following part of the mission statement of L'Arche UK: “Make known the gifts of people with learning disabilities, revealed through mutually transforming relationships."

http://community.larche.org.uk/identity). In this article the distinction is maintained primarily to represent the voice of the core members most clearly. However, it is recognised that the distinction between core members and assistants is relative in the context of L'Arche. Moreover, as said, the answer to the question of how the essences of joy according to core members and assistants might be related to each other further shows how L'Arche should be seen as one community rather than as two distinct groups of people.

We propose that the connection between these essences of joy is in the lived experience, idea, and reality of being valued. In being valued all the essences of joy that have been discussed are included. First, both the core members and the assistants identified relationships as essential to joy. These relationships are marked by the acceptance of every person. When people experience that they are being accepted and appreciated for who they are, they can start dropping their defence mechanisms. Therefore, people can be themselves, a second theme we identified. The freedom of being oneself in relation to others, is a source of joy. Third, this freedom and joy manifests itself in happiness, in laughter, in fun and jokes, in parties and silliness, a theme we identified with the core members, and which was certainly not absent from the stories of assistants. Celebrations are 
important in L'Arche, and one custom in L'Arche is for everyone to say something they appreciate about the person being celebrated. This is a very affirming custom indeed. Fourth, when people are being valued and seen as a gift to the community, the community will look for opportunities for everyone to flourish. In the case of core members, this might be in terms of involvement in the workshops, in opening the door for a stranger, or the heartfelt acknowledgement that the twinkling in the eye of the least verbal core member has the power to bring the community together. Fifth, one of the opportunities some core members revel in, is to welcome visitors. Moreover, the experience of being welcomed is one of being valued.

Finally, being valued is the key to understanding how joy and tough times go hand in hand. Kevin and Morag told of deep pain that might arise in community life. Joy is not in the pain itself, but the ability to stay together and to go through the difficult times together. This is not unrelated to woundedness as spoken of by Vanier. Through acceptance instead of rejection, through knowing and being known, through realising the gift that each person is to the community and therefore being needed, joy can emerge even from the 'bottom of the hole,' to use Kevin's expression. Josef Pieper once said that love means saying to someone: "It's good that you exist; I am glad that you are here" (cited in Swinton 2012, p. 262). I asked Kevin whether that would be a way to understand the joy of being together at the bottom of a hole, and of going together through difficult times while still seeing each other as a gift to the community. Kevin affirmed that that phrase sums it up indeed. Joy is in valuing the other, even when things get tough.

How might we interpret the essences of joy, and 'being valued' as being the heart of these essences of joy, theologically? It is remarkable that spirituality was mentioned by some participants, though by no means mentioned by all. Nevertheless, being valued as the heart of the essences of joy is a deeply theological concept. This is particularly clear in the writings of two well-known spokespersons for L'Arche, namely Jean Vanier and Henri Nouwen.

The idea of being valued is central to Jean Vanier's thought, often expressed in the phrase 'revealing someone's preciousness.' Talking about love, in his book Becoming Human, he mentions 
seven aspects of love, the first being revealing someone's preciousness. "To reveal someone's beauty is to reveal their value by giving them time, attention, and tenderness. To love is not just to do something for them but to reveal to them their own uniqueness, to tell them that they are special and worthy of attention" (Vanier, 1999, p. 22). This quote is closely related to Vanier's first musings on joy in our interview. The signs of joy are "the eyes that are brighter, an element of welcome, open-ness. The opposite is hardness, closed-ness, whereas joy is a smile, is a relaxation, smile. And yet, there's a light, there's a clarity." According to Vanier this welcome goes back to early childhood. This is where a child learns it is precious and loved. Vanier speaks about defence mechanisms immediately following his thoughts on love and preciousness in early childhood: The child "knows to exist is to be precious. And to be loved. But then things come and happen. In a moment he discovers that he's not loved, and defence mechanisms..." Yet ultimately, our love for people needs to be grounded in God's love for us, Vanier writes (1992, pp. 20-21, cf. p. 30):

$$
\begin{aligned}
& \text { We can only truly love people who are different, we can only discover that } \\
& \text { difference is a treasure and not a threat, if in some way our hearts are becoming } \\
& \text { enfolded in the heart of the Father, if somewhere God is putting into our broken } \\
& \text { hearts that love that is in God's own heart for each and every human being. For God } \\
& \text { is truly in love with people, and with every individual human being. }
\end{aligned}
$$

We are reminded of 1 John 4:19: "We love because he first loved us." Vanier argues that each person has a well within them from which tenderness and love flow forth. To each person it should be revealed that they have these waters of life (Vanier, 1992, pp. 27-28). Obviously, within that notion is that to each person it should be revealed that they are precious. By letting down barriers and defence mechanisms, people can start tapping into the well and become a source of joy and life to others. The source of this well is the living water Jesus gives (Jn 4:14; Vanier offers some profound reflections on the story of Jesus and the woman at the well in John 4 in his commentary on the gospel of John (2004); cf. Vanier 2016, pp. 62-67). 
The notion of being valued, and therefore being revealed one's preciousness, is grounded in God's love for people, as Vanier says. Nouwen concurs and claims that the words spoken to Jesus by God at his baptism are true for every person: "This is my Son, whom I love; with him I am well pleased" (Mt. 3:17). For Nouwen these words "revealed the most intimate truth about all human beings ... Being the Beloved expresses the core truth of our existence" (Nouwen, 1992, pp. 30, 33). This truth is to be claimed by everyone themselves, but also for everyone else. In other words, embracing this truth leads to both self-acceptance and seeing the preciousness of the other (cf. Vanier, 1999, pp. 100-101). According to Nouwen, the greatest enemy of the truth of being the beloved, is self-rejection (Nouwen, 1992, p. 31). Rejection by others often leads to self-rejection. Likewise being accepted by others can greatly help to accept oneself.

In his Life of the Beloved, Nouwen (1992) describes the reality of being the beloved in a Eucharistic framework, showing how being beloved might be interpreted in terms of the Eucharistic actions of being taken, blessed, broken and given. Being the beloved does not begin with oneself, but by being taken or chosen by God. Being taken by God, however, also means to be given to the world, just as the bread is taken, blessed, broken and given in the Eucharist; just as Jesus was taken or chosen, was blessed, broken and given for the life of the world. One's belovedness is not something to selfishly cling to, as love never does. Love generates love. In between being taken and being given is a life which includes blessings and brokenness. The more one owns both the blessings and the brokenness, the more one can own one's belovedness and show others they are beloved. Theologically it is significant that Nouwen describes the life of being beloved in Eucharistic terms and at the same time points out that the reality of being beloved goes back to the words spoken at Jesus' baptism. As such, being a beloved child of God is grounded in and nourished by the sacraments, which can be thought of as the heart of the Christian life.

This brief theological reflection on the essences of joy has focused on what is arguably the heart of the essences of joy: each person being valued as they are. Theologically this is grounded in the preciousness of every person, which in turn is grounded in the love of God for all people. 
Imagining ourselves in the L'Arche communities, we might hear each person claiming for themselves the words, "You are my beloved son, you are my beloved daughter" - or at least, that is the invitation Nouwen and Vanier argue is extended by God to every human being. Other theological themes can be developed, such as the value of every person being rooted in creation and incarnation. Space does not permit to develop these themes further, but the one's identified here, on the basis of Nouwen and Vanier, are arguably at the core of a theological interpretation of being valued, and therefore eventually of joy in L'Arche.

\section{Conclusion}

A practical-theological phenomenology of joy looks as follows: the essences of joy are to be found in relationships, being oneself, being given opportunities, welcome, happiness, and somehow joy is found in difficult times. Central to these is the lived reality of being valued. Theologically we can ground this, with the authoritative voices of Vanier and Nouwen, in preciousness and love, and ultimately in the invitation to hear God's words "You are my beloved son, my beloved daughter," spoken to oneself.

L'Arche teaches that joy might look like this: owning the words of "You are my beloved daughter, you are my beloved son," you can own your preciousness. When seeing yourself as someone who is precious, you start accepting yourself as you are. By living in community, you will look into the mirror, held up by fellow community members. The picture the community holds up in the mirror, is one in which there is unconditional acceptance and love. At the same time, you might see your sharp edges and dark corners, areas in your life where you might have put up defence mechanisms, which need to be healed by the loving touch of the community (and from a Christian perspective, by the love of God). The community also tells you that, "despite those edges and corners, you are needed. You belong, you are a gift to the community, and we cannot and want not to do without you. Whether you are a person with disabilities or an assistant, as a community we hope to give you the opportunity to explore your gifts, to learn new skills, to develop deep relationships, to flourish. Whoever you are, whatever your story is, you are welcome. Don't hold up 
appearances, we love you just as you are, so be yourself - that is actually the version we like best. If this is indeed how we live community and how we share our lives together, don't be surprised that there is a lot of happiness, laughter, silliness, fun, jokes. These are not superficial signs of joy - these are the signs of joy that is deeply rooted in the community, where we all recognise each other as precious, as a gift, as beloved children of God."

There is a radical equality and mutuality present in these L'Arche communities, an openness to one another. The joyful witness of these communities speaks outside of the context of L'Arche. The central place of relationships and mutuality often contrasts with other care providers, which work from a service model and in which forming friendships is sometimes actively discouraged. While one might rightly reply that care providers are often understaffed and under-resourced, L'Arche's recognition of each person's value and preciousness invites reflection on underlying philosophies of care and humanness.

\section{Acknowledgments}

This publication was made possible through the support of a grant from the John Templeton Foundation, through the Yale Centre for Faith and Culture. The opinions expressed in this publication are those of the authors and do not necessarily reflect the views of the John Templeton Foundation or the Yale Centre for Faith and Culture.

We are grateful for the L'Arche communities in Inverness (now Highlands), Manchester, Trosly and Kenya for welcoming us in their communities and participating in this project. We have learned much more from them than any academic article can ever express.

\section{Notes}

1. L'Arche was founded in Trosly-Breuil, France, in 1964 by Jean Vanier. There are currently about 150 communities worldwide. https://www.larche.org/en/in-the-world\#all, last accessed October $31^{\text {st }}$ 2018.

2. For example, this is depicted within Henri Nouwen's account of his time spent with Adam, a core member of L'Arche Daybreak (Toronto). Henri J. M. Nouwen, Adam: God's Beloved (London: Darton,Longman \& Todd Ltd, 1997). 


\section{References}

Barth, K. (1956). Church Dogmatics (Vol. III/4). Edinburgh: T \& T Clark.

Finlay, L. (2008). A Dance Between the Reduction and Reflexivity: Explicating the 'Phenomenological Psychological Attitude'. Journal of Phenomenological Psychology, 39(1), 1-32.

Moltmann, J. (1973). Theology and Joy. London: SCM Press Ltd.

Moschella, M. C. (2016). Caring for Joy: Narrative, Theology, and Practice. Leiden and Boston: Brill. Nind, M. (2008). Conducting qualitative research with people with learning, communication and other disabilities: Methodological challenges. ESRC National Centre for Research Methods. Retrieved from http://eprints.ncrm.ac.uk/491/1/MethodsReviewPaperNCRM-012.pdf Nouwen, H. J. M. (1992). Life of the Beloved: Spiritual Living in a Secular World. New York: The Crossroad Publishing Company.

Nouwen, H. J. M. (1997). Adam: God's Beloved. London: Darton,Longman \& Todd Ltd.

Vanier, J. (1992). From Brokenness to Community. New York and Mahwah: Paulist Press.

Vanier, J. (1999). Becoming Human. London: Darton, Longman, and Todd.

Vanier, J. (2004). Drawn into the Mystery of Jesus through the Gospel of John. London: Darton, Longman \& Todd Ltd.

Vanier, J. (2007). Community and Growth (Rev. Ed.). London: Darton, Longman, and Todd. Vanier, J. (2016). Life's Great Questions. London: SPCK.

Volf, M., \& Crisp, J. E. (Eds.). (2015). Joy and Human Flourishing: Essays on Theology, Culture and the Good Life. Minneapolis: Fortress Press. 